\title{
Molecular Docking of Lunacridine from Lunasia amara to DNA: Its Inhibition and Interaction Study Correlated with The Cytotoxic Activity on P388 Murine Leukemia Cells
}

\author{
M. Sulaiman Zubair ${ }^{1}$, , Subehan $^{2}$ \\ ${ }^{1}$ Faculty of Mathematics and Natural Sciences, Tadulako University, \\ Soekarno Hatta Street, Palu, 90411, Indonesia \\ ${ }^{2}$ Faculty of Pharmacy, Hasanuddin University, \\ Perintis Kemerdekaan km.10 Street, Makassar, 90245, Indonesia
}

\begin{abstract}
DNA Topoisomerase II inhibitors are a type of anticancer drugs. These drugs perform their biological activity either by forming a DNA-intercalator-topoisomerase II ternary complex or by inhibiting other enzymes and/or transcription factors that act on DNA. The strong interactions with DNA play a crucial role for their pharmacological properties. Lunacridine, the active principle from Lunasia amara, was known as DNA intercalating Topoisomerase II inhibitor. With the aims to explore the affinity and molecular interaction of lunacridine compound isolated from Lunasia amara with DNA, molecular docking study has been carried out with DNA model using Autodock 4.0 software. Cytotoxicity test on P388 murine leukemia cells was done also using $100,30,10,3$ and I $\mu \mathrm{g} / \mathrm{ml}$ series of lunacridine concentration. The docking result shows that Lunacridine itself could to dock intercalatively between base pairs of DNA and the possibility interaction with adenine, thymine and cytosine by dipole-dipole interaction. The lowest predicted binding energy of lunacridine is $-6,22 \mathrm{kcal} / \mathrm{mol}$, whereas original ligand bis thiazole is $-16,37 \mathrm{kcal} / \mathrm{mol}$. Lunacridine compound itself has less cytotoxic activity on P388 murine leukemia cells with the $\mathrm{IC}_{50}$ value of $39,52 \mu \mathrm{g} / \mathrm{ml}$ or $129,4 \mathrm{I} \mu \mathrm{M}$. The binding energy of lunacridine on DNA higher than original ligand show that the interaction of lunacridine with DNA is not stable afford the less cytotoxic activity. However, based on the $\mathrm{IC}_{50}$ value, lunacridine could be depeloved as anticancer.
\end{abstract}

Keywords: docking, lunacridine, Lunasia amara, cytotoxic, P388 murine leukimia cells.

\section{INTRODUCTION}

DNA represents one of the most important molecular cellular targets of several anticancer drugs. In broad terms, their mechanism of action involves interfering with DNA processing, thus leading to cell death, usually through invoking apoptosis. Agents of this type interact with the DNA double helix through a variety of mechanisms. Some drugs intercalate between the base pairs of DNA, whereas others alkylate DNA bases in either the minor or major grooves. Some agents cross-link the DNA strands together in either an intrastrand or interstrand manner in either the minor or major grooves, and yet other agents exert their effect by binding to the helix and then cleaving the DNA strands (Thurston, 2007).

DNA Topoisomerase II inhibitors are a type of anticancer drugs. These drugs perform their biological activity either by forming a DNAintercalator-topoisomerase II ternary complex or by inhibiting other enzymes and/or transcription factors that act on DNA. The strong interactions with DNA play a crucial role for their pharmacological properties (Filosa, et al., 2009).

DNA topoisomerase II is an enzyme that can eliminate the positive supercoiling formed in DNA occurs during DNA replication (Yuwono, 2008). Mammalian topoisomerase II is very important in cellular processes including replication, transcription, recombination and chromosome segregation (Bromberg and Osheroff, 2001). Inhibition of this enzyme can inhibit cell division and trigger cell death by apoptosis mechanism via activation of the P53 gene (Martinez, 2005).

\footnotetext{
*Corresponding author e-mail: sulaiman_zubair80@yahoo.co.id
} 
One of the medicinal plants use traditionally in South Sulawesi is Sanrego (Lunasia amara Blanco). This Rutaceae plant is widely known as antibacteria and aphrodisiac. Lunasia amara Blanco was known to contain many types of alkaloids especially quinoline alkaloids. One of the major quinoline alkaloid from Sanrego is lunacridine (Goodwin, 1959). Lunacridine had been reported as DNA intercalating topoisomerase II inhibitor (Prescott, et al., 2007).

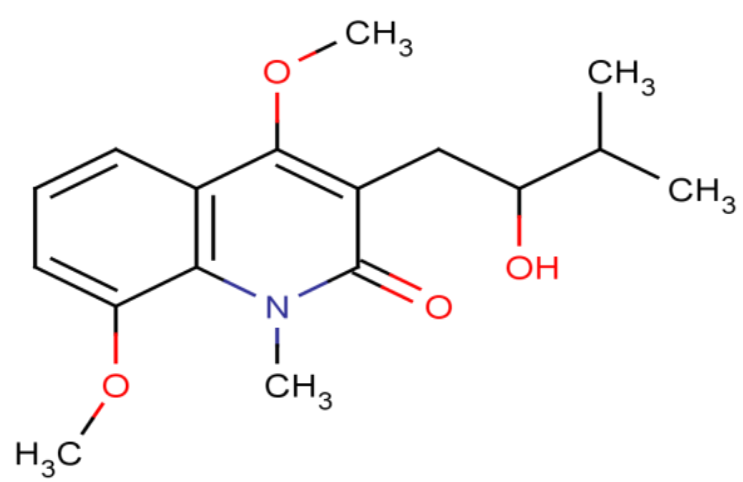

Figure I. Stucture of the lunacridine compound.

\section{METHODS}

\section{Material}

Sanrego lignum (Lunasia amara Blanco) collected from the Siawung Village, Barru Regency, South Sulawesi Province., TLC plates, methanol, n-hexane, ethyl acetate, solvents, organic solvents, silica gel PF254, P388 murine leukemia cells from Natural Products Organic Chemistry Laboratory, Institute of Technology, Bandung, RPMI 1640 medium (sigma), with foetal bovine serum (FBS) 10\%, 2\% kanamycin (Gibco), Hepes (N-2-hidroxyethil-piperazine-2ethanesulfonic acid) (Sigma). $\mathrm{HCl}$ (Merck), Sodium Bicarbonate (NaHCO3) (Sigma); MTT ([3 -(4,5-dimethyl thiazole 2-Joel) -2.5-diphenyl tetrazolium bromide]) (sigma); Sodium Dodecyl Sulphate (SDS) (Merck); Artonin E, and dimethyl sulfoxideltetrahydrofuran (DMSO) (Fluka), Lunacridine standard from Institute of Natural Medicine, Toyama University, Japan, NMR structure of the covalent complex between $\mathrm{d}($ CGCTAGGCG)-(GCGATCCGC) and original ligand bis thiazole obtained from Protein Data Bank online database (www.rcsb.org/pdb) with access code 108D.

\section{Equipment}

VLC was carried out using Merck Si-gel 60, TLC analysis on pre-coated Si-gel plates (Merck
Based on the description above, it had been done exploration of the affinity and molecular interaction of lunacridine to DNA by molecular docking approach and testing its cytotoxic activity on P388 murine leukemia cells by MTT method. This research is expected to be used as a reference in the development effort lunacridine compound to be potential and selective anticancer drug.
Kieselgel $60 \mathrm{~F} 254,0.25 \mathrm{~mm})$. The UV lamp of Spectroline, Model ENF-240 C/F was used to see the spot in TLC. UV and IR spectra were measured with Beckman DU-7000 and Shimadzu FT-IR 8501 Scientific spectrophotometers respectively. For docking simulation using one set of computer with specification Intel ${ }^{\circledR}$ Core $^{\mathrm{TM}} 2$ Duo CPU T5800@ @ 2.00 GHz, RAM 2 GB, Microsoft Windows Xp SP3 operation system, Autodock 4.0 software for docking calculations, MGL Tools 1.5.2, Cygwin, ChemOffice 2004, and Pymol 0.99 rc 6 for visualitation of the docking result.

\section{Molecular Docking Simulation}

Molecular structure of Lunacridine were built using Chem Office 2005 software and geometry optimized using PM3 semiempiric method. Docking study was carried out based on the NMR structure of the covalent complex between d(CGCTAGGCG)-(GCGATCCGC) and original ligand bis thiazole using AutoDock 4.0 software. The crystal structure was downloaded from the protein Data Bank website (www.rscb.org/pdb) with archive code 108D. The original ligand structure was removed from the structure to provide sterically unimpended cavities for ligand docking. Molecular docking calculation for Lunacridine at the intercalation sites of DNA were undertaken using the Lamarckian Genetic Algorithm method with the parameter : a grid box 
size of $42 \times 34 \times 40$ with spacing of $0.375 \AA$ between the grid points, an initial population of 150 randomly placed individuals, a maximum number of $2.5 \times 10^{5}$ energy evaluations, and a maximum number of $2.7 \times 10^{4}$ generations are taken into account. A mutation rate of 0.02 , a crossover rate of 0.8 and local search frequency of 0.06 are used. Data obtained in the form of predicted free energy of binding $(\mathrm{kcal} / \mathrm{mol})$ and predicted inhibition constants $(\mathrm{Ki})$ were recorded and analyzed. Validation of the docking are determined from the value of RMSD (Root Mean Square Deviation) of the original ligand conformation from docking results with actual original ligand conformation (RMSD value must be $\leq 2 \AA$ ). Docking results visualized by using PyMOL for windows software.

\section{Isolation and Identification of Lunacridine}

Dried lignum $(2,1 \mathrm{~kg})$ was extracted by reflux method with methanol for 3 x 24 hours. Reflux process is repeated as many as two times. The filtrate was collected and evaporated to obtain viscous methanol extract $(16.8 \mathrm{~g})$. Methanol extracts then partitioned by using the solvent nhexana and ethyl acetate respectively and evaporated until reached the n-hexane extract $(2.4$ g) and ethyl acetate extract (3.2 g). Ethyl acetate extract was fractionated using $\mathrm{Si}$-gel vacuum liquid chromatography column (VLC) by using combination of eluent. Fractions collected in vial bottles. Each fraction of their chemical components were monitored by TLC using silica gel GF254 stationary phase and mobile phase ethyl acetate: methanol $(25: 1)$. The fraction which has spot with the same Rf value with the spot on TLC for every VLC was then combined to give 5 major fractions. Based on the TLC spots, the fractions which same with Lunacridine standard $\mathrm{Rf}$ value was fractions $2(0.22 \mathrm{~g})$. The fraction 2 was then further subjected with preparative TLC using Sigel as the adsorbent and was eluted with solvents of ethyl acetate: methanol $(25: 1)$ until obtained crystalline of Lunacridine. Identification had been done by TLC using Dragendorf reagent, UV-Vis and IR spectroscopies and compared by Lunacridine standard

\section{MTT Cytotoxic Test Method}

P388 murine cells was cultured in RPMI 1640 medium complemented with 5\% FBS (Fetal Bovine Serum) and Kanamycin $(100 \mu \mathrm{g} / \mathrm{ml})$. Cells ( 3 x 103 cells/well) were cultured in a microplate containing $100 \mu \mathrm{L}$ per well growth medium and incubated at a temperature of $37^{\circ} \mathrm{C}$ in $5 \% \mathrm{CO}_{2}$ humidity atmosphere. Samples with various concentrations added to the culture on the day after transpalantation. On 72 hours, $20 \mu \mathrm{L}$ of MTT solution $(5 \mathrm{mg} / \mathrm{ml})$ per well added into each culture medium. After 4 hours of incubation, $100 \mu \mathrm{L}$ of SDS $10 \%$ solution - $0.01 \mathrm{~N} \mathrm{HCl}$ added into each well and formazan crystals in each well was dissolved with stirring using micropipet. Measurement of optical density (OD) was done using a microplate reader at a wavelength of 550 $\mathrm{nm}$. Media containing only P388 murine cells used as positive control. As a comparison, we used Artonin E. Absorption measurement result implementated of cell death were plotted on the graph of the percentage of cell death versus the concentration of the test sample, then made a calculation of $\mathrm{IC}_{50}$.

$$
\% \text { cell death }=\frac{\text { absorbance cell control-absorbance cell sample }}{\text { absorbance cell control }} \times 100 \%
$$

\section{RESULTS}

\section{Molecular Docking}

1. Geometry Optimation.

Molecular structure of lunacridine was optimized using the PM3 Semiempiric method. Optimization of this structure aims to obtain a stable molecular structure characterized by $\Delta \mathrm{Hf}$ value (entalphy of standart formation) which is minimum. Model of stable molecule can be used for the docking process.

2. Docking Method Validation.

Aims to validate the docking method. Validation of the docking performed in order to choose appropriate parameters to be used in the docking of new compounds. The value of RMSD (Root Mean Square Deviation) is used 
as a validation parameter. Docking method is said to be valid if the RMSD value of $\leq 2 \AA$. From the validation results obtained RMSD value of $1.15 \AA$ indicating that the docking method performed already valid (Figure 2).

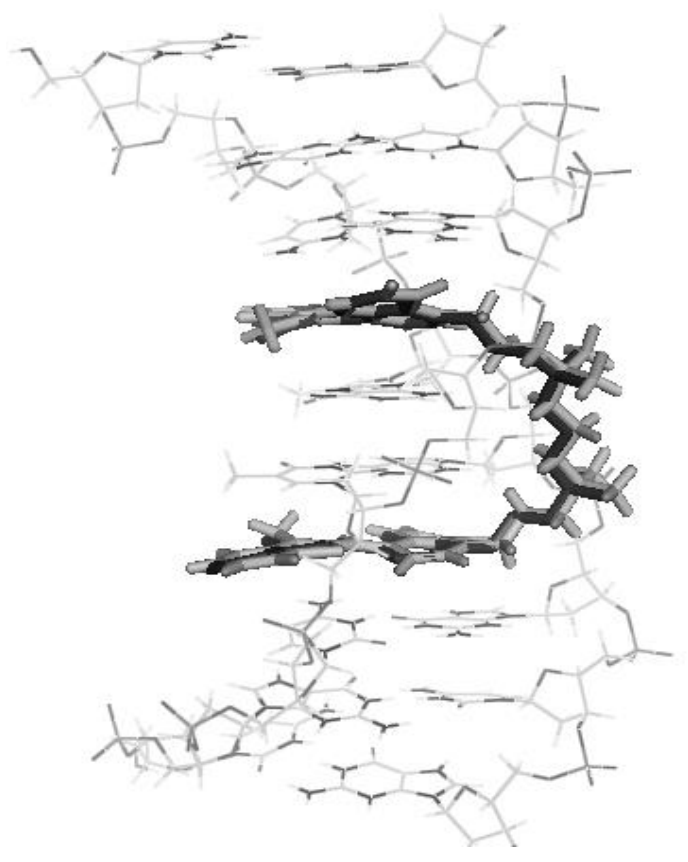

Figure 2. Superimposition in DNA-intercalation site of original ligand bis thiazole conformation from docking (red) and actual original ligand conformation (cyan) with RMSD value of I, I5 A

3. Docking Lunacridine Compound.

Docking study was performed on Lunacridine with DNA model using AutoDock 4.0 software. DNA model was obtained from protein data bank website (www.rscb.org/pdb) with the archive code 108D with original ligand bis thiazole. This model is a representation of DNA topoisomerase II enzyme and has been used by Filosa (2009) as a receptor in the development of model bis-naftalamida compound as a new drug class of DNA topoisomerase II inhibitor with intercalating mechanism. 


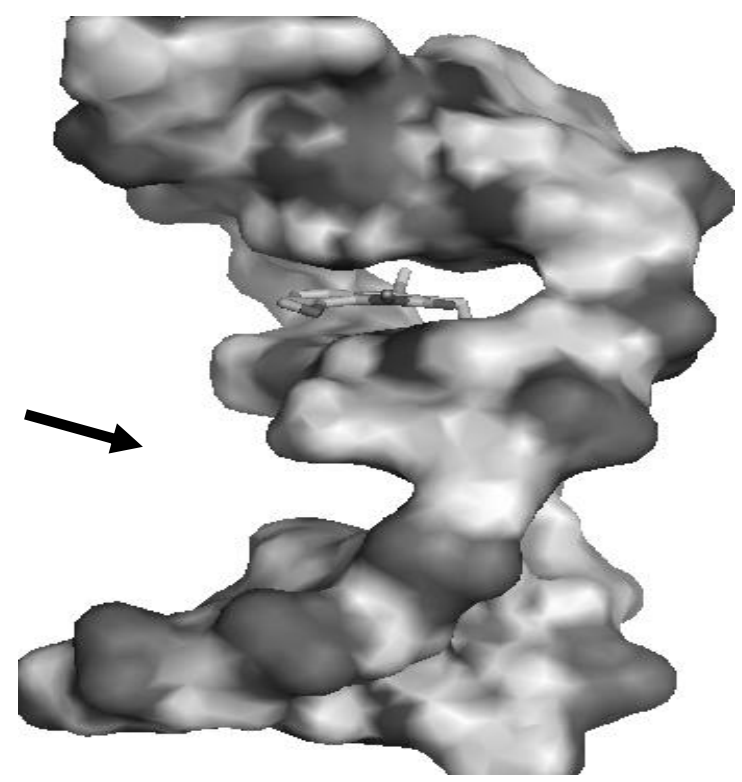

Figure 3. 3D models of the intercalation mode of Lunacridine compound (arrow) on DNA represented by molecular surface

The docking aims to explore the affinity and molecular interaction of lunacridine to DNA. Binding free energy $(\mathrm{kcal} / \mathrm{mol})$ and inhibition constant (Ki) functions were used as parameter of ligand-receptor interaction strength. The docking result on DNA showed that score of lunacridine compound had higher score value compared to original ligand bis thiazole (Table 1). It explains that lunacridine compound affinity on DNA is relatively weak and the interaction of lunacridine with DNA is not stable if compared with original ligand.

Table I. Docking score $(\mathrm{kcal} / \mathrm{mol})$ and inhibition constant $(\mu \mathrm{M})$ prediction of lunacridine

\begin{tabular}{ccc}
\hline Compound & $\begin{array}{c}\text { Predicted Free Binding Energy } \\
(\mathbf{k c a l} / \mathbf{m o l})\end{array}$ & $\begin{array}{c}\text { Predicted Inhibition Constant } \\
(\boldsymbol{\mu M})\end{array}$ \\
\hline Lunacridine & $-6,22$ & $27,5 \mathrm{I}$ \\
Original ligand & $-16,37$ & $0,995 \times 10-6$ \\
\hline
\end{tabular}

\section{Isolation and Identification of Lunacridine}

Isolation using preparative TLC obtained colorless crystalline $( \pm 9 \mathrm{mg})$. Identification of lunacridine isolated using TLC with Dragendorf reagent, UV-Vis and IR spectroscopy. The TLC results showed the same $\mathrm{Rf}$ values with lunacridine standard (Figure 5). 


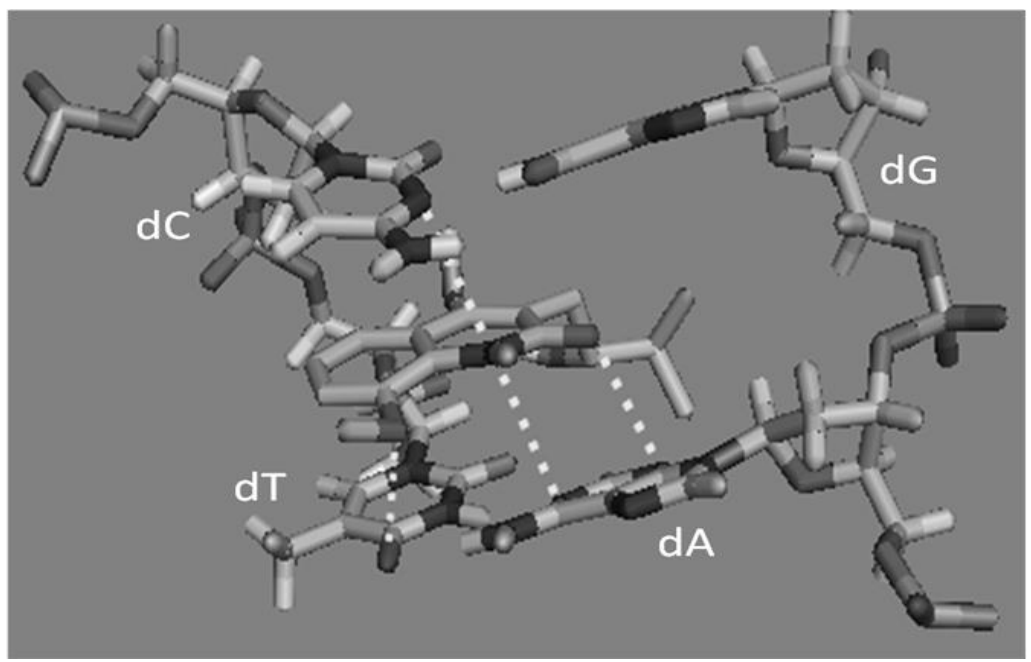

Figure 4. Prediction of interaction between lunacridine compound and DNA

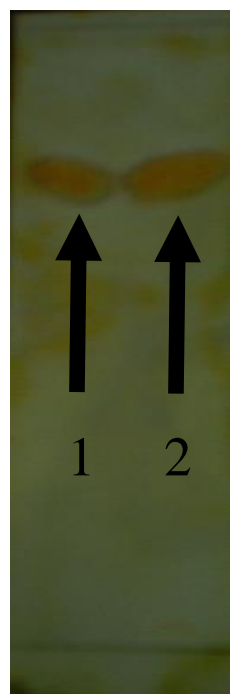

Figure 5. Identification of lunacridine isolated from ethyl acetate fraction of Sanrego (Lunasia amara Blanco) using eluent chloroform: methanol (18:1) after sprayed by dragendorf. I: spot of lunacridine standar as comparison, and 2: spot of lunacridine isolated

The colorless crystal obtained for lunacridine isolated compound has a UV spectrum as shown in Figure 6 with maximum absorbances at $204,216,240,285,298,312$, and $324 \mathrm{~nm}$. This UV spectrum indicated there are subtituted group on quinoline ring (Noerdin, 1986). 


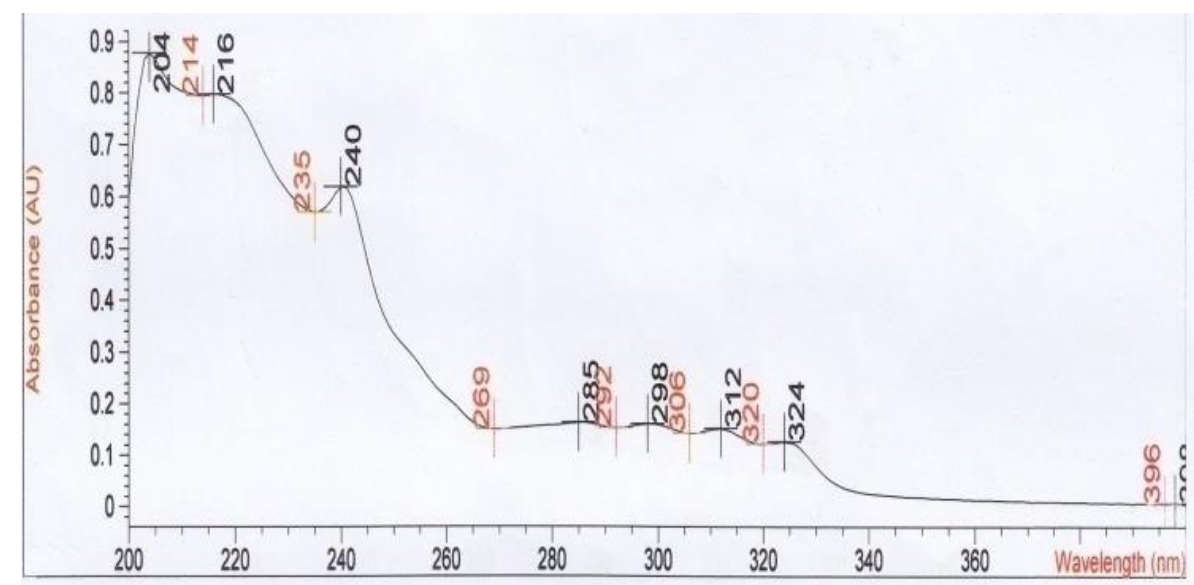

Figure 6. UV-Vis spectrum of lunacridine isolated

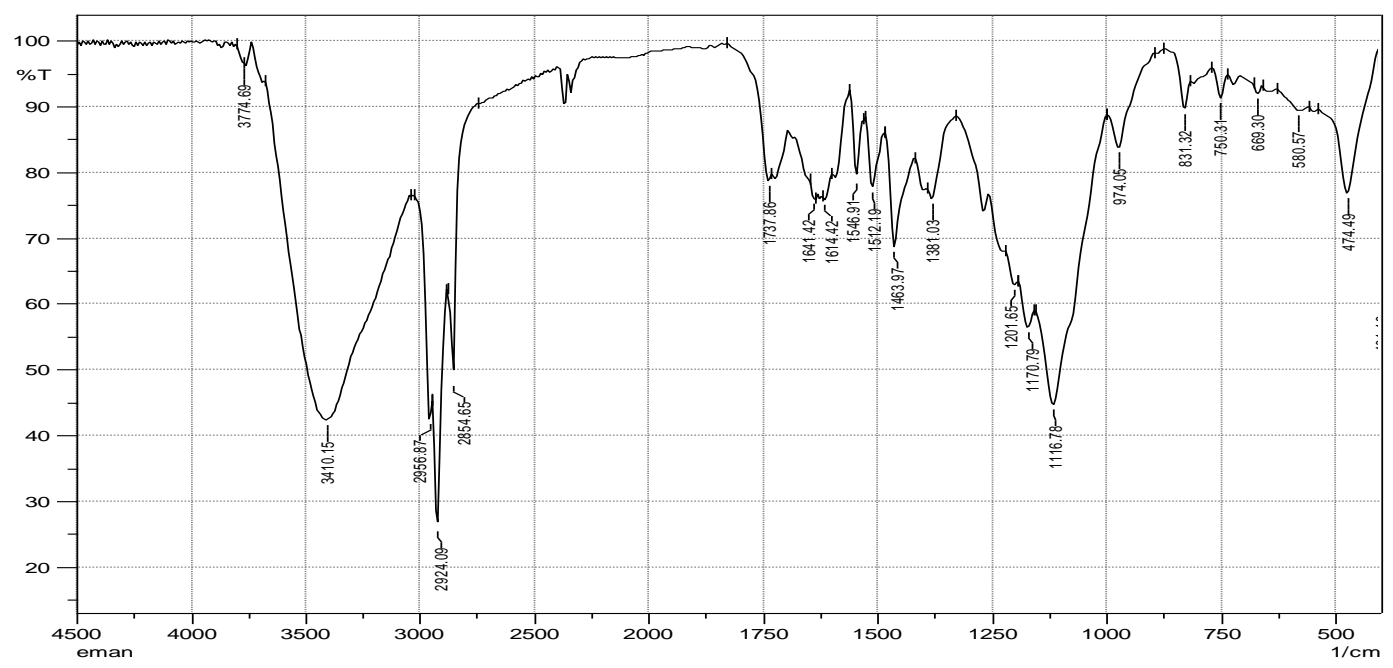

Figure 7. IR spectrum of lunacridine isolated

The IR spectrum of Lunacridine isolated compound (Figure 7) indicated absorption in $\mathrm{KBr}$ $\left(\mathrm{cm}^{-1}\right)$ : 3774,69, 3410,15, 2956,87-2854,65, 1737, $86,1641,42,1546,91,1512,19,1463,97,1201,65$, $1170,79,1116,78$ and 750,31 . The stretching at $3774,69 \mathrm{~cm}^{-1}$ indicated the $\mathrm{NH}$ group. the strong stretching at $3410,15 \mathrm{~cm}^{-1}$ indicated the $\mathrm{OH}$ group, the present of aliphatic $\mathrm{CH}$ group shown by strong stretching at $2956,87-2854,65 \mathrm{~cm}^{-1}$, the present of secondary amide group shown by strong stretching at $1641,42 \mathrm{~cm}^{-1}$, the present of aromatic system is shown by the stretching at 1546,91-1512,19 $\mathrm{cm}^{-1}$, and the present of C-O/C-O-C group shown by the stretching at 1201,$65 ; 1170,79$ and $1116,78 \mathrm{~cm}^{-1}$ (Silverstein, 2005).
Based on the UV and IR spectroscopies data above, the values obtained are similar to Lunacridine reported by Ahmad et al. (2003), therefore it was suggested that the compound isolated is Lunacridine (Table 2) with the molecule structure as shown in Figure 1. 
Table II. The comparison of UV-Vis and IR spectrum datum of lunacridine (Ahmad, et al, 2003) and lunacridine compound isolated

\begin{tabular}{cccc}
\hline \multicolumn{2}{c}{ UV, $\boldsymbol{\lambda}$ max nm } & \multicolumn{2}{c}{ IR, $\mathbf{~ m m}^{-\mathbf{I}}$} \\
\hline $\begin{array}{c}\text { Compound } \\
\text { isolated }\end{array}$ & Lunacridine & Compound isolated & Lunacridine \\
\hline 204 & - & 3774,69 & $3500-3400$ \\
216 & - & 3410,15 & $3500-3400$ \\
240 & 240 & 2854,$65 ; 2924,09 ; 2956,8$ & - \\
285 & 256 & 1546,$91 ; 1512,19$ & 1589,1565 \\
298 & 286 & $164 \mid, 42$ & 1647 \\
312 & 295 & 1201,$65 ; \mid 1170,79 ; 1116,78$ & 1240,1209 \\
324 & 335 & 3774,69 & $3500-3400$ \\
\hline
\end{tabular}

\section{MTT Cytotoxic Test Method}

On testing the cytotoxic activity against P388 murine leukemia cells with a series of concentrations of $100,30,10,3$, and $1 \mu \mathrm{g} / \mathrm{ml}$, lunacridine compound gave $\mathrm{IC}_{50}$ value of 39.52 $\mu \mathrm{g} / \mathrm{ml}$ or $129,41 \mu \mathrm{M}$ (Table 3 ). IC $\mathrm{IC}_{50}$ value reached by regression analysis only using 3 concentrations $(100,30$, and $10 \mu \mathrm{g} / \mathrm{ml})$, because only these datum located on sigmoid area (Figure 8). According Muhtadi (2005), $\mathrm{IC}_{50}$ value above $4 \mu \mathrm{g} / \mathrm{ml}$ indicate that the compound had less cytoxicity on P388 murine leukemia cells.

Table III. Result of the cytotoxicy assay of lunacridine on P388 murine leukemia cells

\begin{tabular}{ccccc}
\hline Sample & $\begin{array}{c}\text { Concentration } \\
(\mu \mathrm{g} / \mathrm{ml})\end{array}$ & $\begin{array}{c}\text { Cell death } \\
(\%)\end{array}$ & & \multicolumn{2}{c}{ IC $_{50}$} \\
\cline { 3 - 5 } & 100 & 83,000 & & \\
\hline \multirow{2}{*}{ Lunacridine } & 30 & 40,428 & & \\
& 10 & 7,656 & 39,52 & $|29,4|$ \\
& 3 & 13,629 & & \\
\hline
\end{tabular}

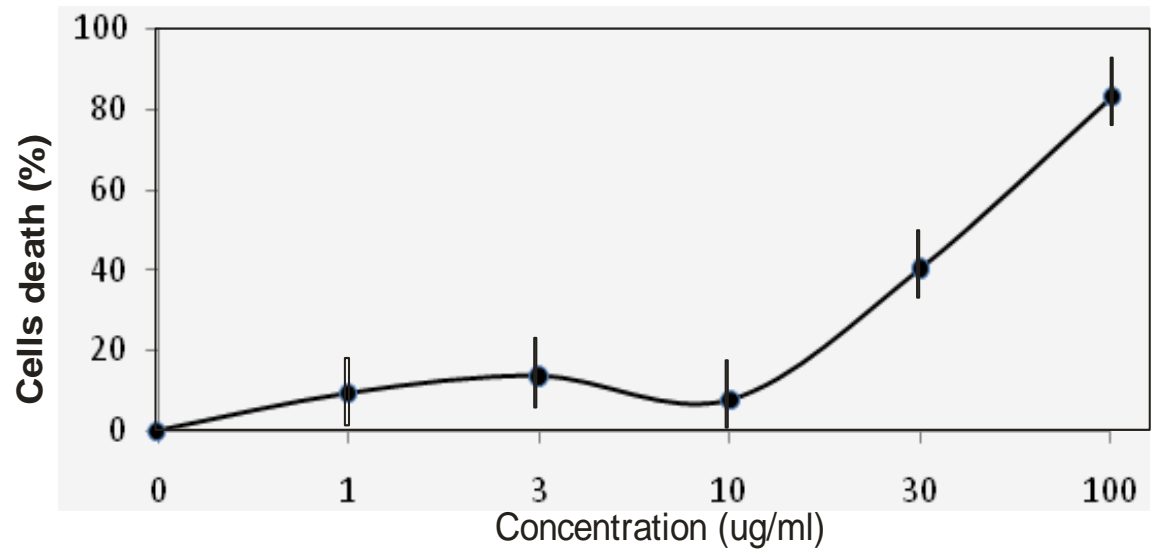

Figure 8. Cells death percentage of P388 murine leukemia cells exposed lunacridine for 72 hours 


\section{DISCUSSION}

The inhibitory potency of the compound on the receptor responsible for development of cancer drugs, could be studied by finding the interaction strength between the compound and the receptor through docking process. It is predicted that the potency will be higher when the interaction strength is stronger (Halperin, 2002). The cytotoxic effect caused by a drug compound is correlated by the docking result. This research showed that Lunacridine from Lunasia amara Blanco has less cytotoxic activity on P388 murine leukemia cells with $\mathrm{IC}_{50}=39,52 \mu \mathrm{g} / \mathrm{mL}$ or 129,41 $\mu \mathrm{M}$. The less cytotoxic activity of lunacridine compound on P388 murine leukemia cells was strong reasonably. Based on the docking result, lunacridine compound has low affinity to interact with DNA with predicted binding free energy of $6.22 \mathrm{kcal} / \mathrm{mol}$ and predicted inhibition constant of $27,51 \mu \mathrm{M}$ if compared with the predicted binding free energy and inhibiton constant of the original ligand bis thiazole of $-16.37 \mathrm{kcal} / \mathrm{mol}$ and $0,995 \mathrm{x}$ $10^{-6} \mu \mathrm{M}$ respectively. This result also show that lunacridine has binding energy higher than original ligand bis thiazol. It means that the interaction of lunacridine with DNA is not stable afford the less cytotoxic activity of lunacridine on cancer cells.

The analysis of docking results accord with the ability of lunacridine to intercalate between base pairs of DNA, which had been reported by Prescott (2007). From docking simulation result gave ten model intercalations of lunacridine to DNA and lunacridine more prefer to intercalate between $\mathrm{CG}$ and TA base pairs than GC and AT base pairs, whereas the side chain of lunacridine located on the minor groove of DNA. Quinoline ring of lunacridine could to perfectly intercalate between DNA base pairs and make л-л interaction with purine and pyrimidine bases of DNA because of the planar structure of quinoline ring (Figure 3). The active sites of lunacridine interacted to DNA are located on $\mathrm{N}$ heterosiclic of the quinoline ring, subtituent of methoxy group (-OCH3) on $\mathrm{C} 8$ of quinoline ring and subtituent of carboxyl group ($\mathrm{C}=\mathrm{O}$ ) on $\mathrm{C} 2$ of quinoline ring. The possibility interaction occurred with adenine, cytosine and thymine by dipole-dipole interaction. In details, the possibility interaction occured between $\mathrm{N} 1$ of quinoline ring and $\mathrm{N} 1$ of adenine, DA5 (3,51 $\AA$ ), carboxyl group $(-\mathrm{C}=\mathrm{O})$ on $\mathrm{C} 2$ of quinoline ring and N3 of adenine, DA5 (3,18 $\AA$ ), methoxy group $\left(\mathrm{OCH}_{3}\right)$ on $\mathrm{C} 8$ of quinoline ring and carboxyl group $(\mathrm{C}=\mathrm{O} 7)$ of thymine, DT4 $(3,21 \AA), \mathrm{N} 1$ of quinoline ring with $\mathrm{N} 3$ of cytosine, DC3 $(3,41 \AA)$. The other subtituent such as methoxy group
$\left(\mathrm{OCH}_{3}\right)$ on $\mathrm{C} 4$ of quinoline ring, side chain of lunacridine and $\mathrm{OH}$ group on lunacridine side chain didn't show dipole-dipole interaction with DNA (Figure 4). Therefore, this study suggest to modify these groups to increase the amount of molecular interaction of lunacridine to DNA and to increase the cytotoxic potency of lunacridine.

Although there is a relationship between the binding free energy of lunacridine reached by docking simulation and its cytotoxic activity, as discussed above, cytotoxicity is not only dependent on the ability to interact with DNA. According to Martinez (2005), there are also many DNA intercalators that are incapable of working as cytotoxic agents. To be effective, a drug must first overcome many barriers, including metabolic pathways, and cytoplasmic and nuclear membranes (Martinez, 2005). Once the drug is situated in the nucleus, it must be capable of interacting with DNA by intercalating that is, forming a stable complex with a relatively long halflife. Achieving entry into the nucleus and forming a DNA complex are only the first stages of a series of events that underlie the cytotoxic activity of DNA intercalators, thus cytotoxicity is more than just an interaction with DNA. Cytotoxicity is a consequence of the poisoning of topoisomerase, enzymes that are directly involved in DNA recognition, in the fundamental steps of cellular growth when DNA replication is active, in the $S$ phase of the cell cycle, in which the topology of DNA plays a significant role. Topoisomerase enzim also work and can be poisoned, in the $\mathrm{M}$ phase of the cell cycle and arranging the chromatin.

By this study, we know that lunacridine could be as a lead compound for anticancer drug based on the $\mathrm{IC}_{50}$ value on P388 murine leukemia cells and the ability to intercalate on DNA. Therefore, it is needed further study to increase the cytotoxic activity of lunacridine by considering some factors mentioned above such as affinity and molecular interaction with DNA, the absorpsion ability on cell membrane, the polarity properties, and the ability to form stable complex with DNA with a relatively long halflife.

\section{CONCLUSION}

From docking simulation of lunacridine to DNA, gave the result of predicted binding energy of lunacridine on DNA is $-6,22 \mathrm{kcal} / \mathrm{mol}$, whereas original ligand bis thiazole is $-16,37 \mathrm{kcal} / \mathrm{mol}$. Binding energy of lunacridine higher than original ligand show that the interaction of lunacridine with DNA by intercalating mechanism is not stable 
afford the less cytotoxic activity of lunacridine on cancer cells. The ability of lunacridine to intercalate on DNA based on the planar structure of the quinoline ring.

\section{ACKNOWLEDGMENT}

The author would like to thank to BPPS DIKTI for supporting grant for this research.

\section{REFERENCES}

Bromberg, K.D. and Osheroff, N., 200I, DNA Cleavage and Religation by Human Topoisomerase II Alpha at High Temperature, Biochemistry, 40, 84I0-84I8.

Filosa, R., Peduto, A., In Micco, S, de Caprariis, P., Festa, M., Petrella, A., Capranico, G. and Gifulco, G., 2009, Molecular Modeling Studies, Synthesis and Biological Activity of a Series of Novels and on Their Bisnaphthalimides as New Development of DNA Topoisomerase II Inhibitors, Bioorg. Med. Chem., 17, 13-24.

Goodwin, S., Smith, A.F., Velasquez, A.A. and Horning, E.C., 1959, Alkaloids of Lunasia amara Blanco. Isolation Studies, J. Am. Chem. Soc., 8I, 6209-62I3.

Halperin, I. Ma, B. Wolfsom, and H. Nussinov,R., 2002, Principles of Docking : An Overview of
Search Algorithms and A Guide to Scoring Functions, Proteins, 47: 409-443

Martinez, R. and Garcia, LC., 2005, The Search of DNA-Intercalators as Antitumoral Drugs: What it Worked and What did not Work, Curr. Med. Chem., I 2, I27-I5I.

Muhtadi, Euis H. Hakim, Yana M. Syah, Lia D. Juliawaty, Sjamsul A. Achmad, Ikram M. Said, and Jalifah Latip, 2005, Three Compounds of Skin Stem Oligostilbenoid retusus Blume Dipterocarpus (Dipterocarpaceae), Journal of Mathematics and Science, 10(4), I37-I43.

Noerdin, D., 1986, Structure Elucidation of Organic Compound by UV and IR Spectroscopy, Angkasa Press, Bandung.

Prescott, A.K., Maciver, S.K., Sadler, I.H. and Kiapranis, R., 2007, Lunacridine from Lunasia amara is a DNA Intercalating Topoisomerase II Inhibitors, Journal of Ethnopharmacology, 109, 289-294.

Silverstein, R.M., Webster, F.X. and Kiemle, D.J., 2005, Spectrometric Identification of Organic Compounds, 7rd, John Wiley \& Sons, Inc., New York.

Thurston, E. And David., 2007, Chemistry and Pharmacology of Anticancer Drugs., CRC Press, Boca Raton, FL, 58,

Yuwono, T., 2008, Molecular Biology, Erlangga Publisher, Jakarta, 102, 